JAMP: Jurnal Adminitrasi dan Manajemen Pendidikan

Volume 4 Nomor 4 Desember 2021, Hal : 320 - 330

Tersedia Online di http://journal2.um.ac.id/index.php/jamp/

ISSN 2615-8574 (online)

\title{
PENGARUH PENGGUNAAN PEMBELAJARAN DARING TERHADAP HASIL BELAJAR SISWA
}

\author{
Novi Niken Pratiwi, Durinda Puspasari
}

\author{
Program Studi Pendidikan Administrasi Perkantoran,Fakultas Ekonomika dan Bisnis, \\ Universitas Negeri Surabaya, Jl Ketintang No. 2 Surabaya \\ E-mail: novi.17080314100@mhs.unesa.ac.id No. HP 085604669027
}

\begin{abstract}
This study aims to analyze the effect of using online learning on student learning outcomes in the subjects of General Administration class X OTKP SMK Muhammadiyah 7 Gondanglegi Malang. This research is quantitative. The data collection technique used is a questionnaire. The population in this study was 113 students of class X OTKP at SMK Muhammadiyah 7 Gondanglegi Malang. The sample in this study was 88 students using proportional random sampling. The test of the instrument consisted of a validity test and a reliability test. Data analysis techniques include: 1) classical assumption test consisting of normality test and heteroscedasticity test; 2) hypothesis testing using simple linear regression. The results no significant effect online learning on student learning outcomes in the subjects of General Administration class X OTKP SMK Muhammadiyah 7 Gondanglegi Malang.
\end{abstract}

Keywords: Online Learning; Student Learning Outcomes.

\begin{abstract}
Abstrak : Penelitian ini bertujuan untuk menganalisis pengaruh penggunaan pembelajaran daring terhadap hasil belajar siswa pada mata pelajaran Administrasi Umum kelas X OTKP SMK Muhammadiyah 7 Gondanglegi Malang. Penelitian ini merupakan penelitian kuantitatif. Teknik pengumpulan data yang digunakan adalah angket. Populasi dalam penelitian ini adalah siswa kelas X OTKP di SMK Muhammadiyah 7 Gondanglegi Malang sebanyak 113 siswa. Sampel dalam penelitian ini sebanyak 88 siswa dengan menggunakan proportional random sampling. Uji coba instrumen terdiri dari uji validitas dan uji reliabilitas. Teknik analisis data mencakup: 1) uji asumsi klasik yang terdiri dari uji normalitas dan uji heteroskedastisitas; 2) uji hipotesis menggunakan regresi linier sederhana. Hasil penelitian menunjukkan bahwa tidak terdapat pengaruh signifikan penggunaan pembelajaran daring terhadap hasil belajar siswa pada mata pelajaran Administrasi Umum kelas X OTKP SMK Muhammadiyah 7 Gondanglegi Malang.
\end{abstract}

Kata Kunci: Pembelajaran Daring; Hasil Belajar Siswa.

pendidikan adalah proses akademik yang tujuannya guna meningkatkan suatu nilai budaya, sosial, budaya, serta agama, dan juga mempersiapkan pembelajar menghadapi tantangan dan pengalaman dalam kehidupan nyata (Munir, 2009) . Dalam penelitian yang dilakukan (Valentina, Nugrahadi and Budiarta, 2019) menyatakan pendidikan ialah suatu cara untuk menghasilkan Sumber Daya Manusia (SDM) dengan pengalaman, perubahan, keterampilan, dan sikap. Sehingga pendidikan sangatlah penting bagi seseorang untuk mendapatkan pengetahuan serta dapat mengembangkan potensi diri. Kegiatan pembelajaran sebelum adanya pandemi covid-19 dilakukan secara tatap muka langsung dengan guru dengan melakukan kegiatan pembelajaran di sekolah. Namun sejak adanya wabah covid-19 atau yang lebih dikenal dengan coronavirus 19, pendidikan di Indonesia lebih menekankan pada pembelajaran daring atau online. Penyakit coronavirus 19 (covid-19) adalah infeksi virus yang sangat mudah menular dan patogen yang disebabkan oleh sindrom pernafasan akut parah coronavirus 2 (SARS-CoV-2) yang muncul di Wuhan, Cina serta menyebabkan penyebaran ke penjuruh dunia. Analisis genomik merupakan SARS-CoV-2 secara filogenetik berhubungan dengan virus kelelawar semacam sindrom 
pernafasan akut parah mirip SARS, dengan demikian itu kelelawar dapat menjadi reservoir utama yang mungkin sumber berasalnya virus dengan mentransfe virus pada manusia yang tidak diketahui, namun perpindahan manusia ke manusia yang cepat telah dikonfirmasi secara luas (Shereen et al., 2020).

Penyebaran covid-19 di Indonesia sangat pesat sehingga membuat Kementerian Pendidikan dan Kebudayaan Republik Indonesia memberikan tanggapan terhadap situasi tersebut dengan mengeluarkan kebijakan belajar di rumah untuk ikut membantu memutus mata rantai penyebaran covid-19 serta agar tidak mengganggu proses belajar mengajar yang sedang berlangsung di tengah masyarakat (Melinda and Lazwardi, 2020). Sehingga pada saat pandemi covid-19 ini masyarakat harus tetap berada di rumah (stay at home) dengan bekerja, beribadah, serta melakukan belajar dari rumah. Dengan ini pendidikan di seluruh belahan dunia salah satunya di Indonesia melakukan kegiatan belajar mengajar di rumah, salah satunya dengan menggunakan pembelajaran daring. (Ismawati, 2017) menyatakan belajar ialah suatu proses untuk mewujudkan perubahan dalam diri peserta didik baik dalam segi kognitif, psikomotorik, dan afektif yang dilakukan oleh peserta didik di sekolah dengan bimbingan guru untuk mencapai tujuan pendidikan yang terlihat dari hasil belajar peserta didik.

Pembelajaran daring merupakan pembelajaran yang digunakan oleh seseorang untuk mendapatkan ilmu pengetahuan. (Abdeldayem, Aldulaimi and Abdulrazaq, 2020) juga menyatakan bahwa dalam pembelajaran virtual, mahasiswa dan dosen dapat berkomunikasi melalui berbagai cara seperti internet, intranet, ekstranet, atau TV interaktif serta pembelajaran virtual dapat dianggap sebagai penggunaan terbaik sumber daya manusia dan materi untuk mahasiswa dan universitas. (Melinda and Lazwardi, 2020) menyatakan bahwa pembelajaran daring adalah proses pembelajaran yang dilakukan dengan terhubung melalui jaringan internet atau secara online. Diketahui bahwa kegiatan belajar dapat dilakukan di mana saja dan kapan saja, seseorang mulai dari kecil hingga dewasa dapat melakukan belajar. Pembelajaran berbasis online merupakan pembelajaran untuk mendapatkan ilmu pengetahuan melalui daring. Kegiatan belajar dilakukan kapan saja dan juga dimana saja, seseorang mulai dari kecil hingga dewasa dapat melakukan belajar. Pembelajaran online saat ini menjadi pilihan untuk digunakan siswa belajar karena fleksibel, yang memungkinkan siswa dapat mengakses informasi maupun sumber informasi belajar tanpa adanya batas ruang dan waktu (Prasetya and Harjanto, 2020). Sama halnya pada saat ini proses belajar dilaksanakan di rumah masing-masing melalui pembelajaran daring atau jarak jauh dilaksanakan untuk dapat memberikan pengalaman belajar yang baru dan bermakna bagi siswa dimana pembelajaran dilakukan melalui tanpa tatap muka dengan guru namun melalui media sosial maupun bantuan media lain yang mendukung untuk pembelajarannya. Pembelajaran daring yang digunakan bantuan media sosial yang ada seperti: WhatsApp, Zoom, Google Classroom, Ruang Guru, Edmodo maupun media pembelajaran yang dapat digunakan sebagai penunjang kegiatan pembelajaran. Pembelajaran daring memudahkan siswa untuk melakukan pembelajaran dimana siswa tidak perlu pergi ke sekolah untuk melakukan kegiatan belajar. Dengan pembelajaran daring saat ini tentunya sekolah mengharapkan siswa dapat menerapkan pembelajaran daring dengan baik, serta mendapatkan pengetahuan baru melalui pembelajaran daring saat ini. Namun dari kemudahan yang diperoleh dalam pembelajaran daring tentunya masih terdapat permasalahan yang dialami oleh siswa seperti terdapat siswa yang belum memahami betul akan penggunaan pembelajaran daring, pengeluaran untuk pembelajaran daring tidak sedikit, dan apabila terkendala oleh sinyal pada saat pembelajaran berlangsung tentunya membuat pembelajaran terganggu serta rumah siswa tersebut di daerah terpencil pembelajaran online dirasa kurang efektif dan efisien apabila terus-menerus digunakan untuk proses pembelajaran.

Adapun indikator yang dijadikan ukuran dalam penggunaan pembelajaran daring dalam penelitian ini menurut (Widiyono, 2020), antara lain: 1) lokasi selama perkuliahan daring saat pandemi covid-19; 2) jenis koneksi internet selama perkuliahan daring; 3) kondisi sinyal internet selama perkuliahan daring; 4) media yang sering dipergunakan selama perkuliahan daring; 5) aplikasi yang sering dipergunakan selama perkuliahan daring; 6) pemahaman pembelajaran daring selama pandemi covid-19; 7) sistem perkuliahan yang diharapkan mahasiswa selama pandemi covid-19; 8) kendala dalam perkuliahan daring di saat pandemi covid-19;9) kesiapan terhadap the new normal live di saat pandemi covid-19.

Dalam penelitian (Bahasoan et al., 2020) menyatakan bahwa pembelajaran online ini tetap saja memiliki beberapa kelemahan, diantaranya sinyal yang sulit dijangkau oleh siswa yang tinggal di 
daerah, banyak chat yang meembuat memori handphone penuh sehingga koneksi internet lambat dan lumayan melelahkan karena mereka harus bolak-balik melihat obrolan dari awal belajar. Sedangkan penelitian (Wilson, 2020) menyatakan e-learning dapat mengurangi interaksi dosen dengan mahasiswa dan antarmahasiswa. Keadaan ini mengharuskan para dosen agar lebih teliti dan kreatif untuk memilih metode yang dapat digunakan serta diterapkan terhadap mahasiswa, maka dengan demikian mahasiswa tidak akan merasa cepat bosan saat menerima materi juga mengerjakan tugas-tugas yang dibagikan dosen. Dengan demikian dalam penggunaan pembelajaran daring dapat mempengaruhi hasil belajar siswa.

Hasil belajar diperoleh ketika peserta didik telah mendapatkan keberhasilan, pengalaman dari proses belajarnya. Hasil belajar siswa dapat berupa keahlian atau kemampuan yang dimiliki, dan mendapatkan nilai. Suatu hal penting bagi siswa untuk mengetahui nilai yang diperoleh setelah mengerjakan tugas ulangan harian, menyelesaikan ujian tengah semester, serta menyempurnakan nilai dengan hasil ujian akhir semester. (Ida and Maksum, 2020) menyatakan hasil belajar tidak hanya berguna dalam menentukan apakah tujuan instruksional tercapai, namun perubahan perilaku siswa, serta hasil belajar juga merupakan umpan balik untuk mengembangkan suatu proses belajar. (Mustakim, 2020) menyatakan hasil belajar dapat dimaknai sebagai segala sesuatu yang terjadi di kelas antara peserta didik dan pendidik dengan penilaian tertentu yang sebelumnya sudah ditetapkan berdasarkan kurikulum di lembaga pendidikan tersebut. Hasil belajar menurut (Amiruddin, 2016) dapat dibagi menjadi tiga yakni: 1) kognitif merupakan suatu yang membahas tujuan pembelajaran berkenaan dengan proses mental yang berawal dari tingkat pengetahuan sampai pada tingkat yang lebih tinggi yakni evaluasi, a) pengetahuan (knowledge), b) pemahaman (comprehension), c) aplikasi (application), d) analisis (analysis), e) sintesis (synthesis), f) evaluasi (evaluation); 2) afektif ialah satu domain yang berkaitan dengan sikap dan nilai-nilai interes, apresiasi, dan penyesuaian perasaan sosial; 3) psikomotor.

Dari beberapa pendapat tersebut dapat disimpulkan bahwa hasil belajar diperoleh siswa setelah mendapatkan keberhasilan, pengalaman dari suatu proses pembelajaran dimana hasil belajar tersebut dapat berupa keahlian atau kemampuan yang dimiliki, serta dengan mendapatkan nilai dari proses hasil belajar. Dengan demikian hasil belajar yang baik akan diperoleh apabila siswa rajin belajar, dapat memahami materi dengan baik, selalu termotivasi untuk belajar, adanya media yang menunjang pembelajaran serta siswa menggunakan hasil belajar yang telah diperoleh sebagai evaluasi diri. Begitu pula dengan penggunaan pembelajaran yang tepat tentunya dapat memudahkan siswa untuk melakukan pembelajaran, seperti saat ini pembelajaran dilakukan secara online sehingga mempermudah siswa untuk belajar mandiri, siswa dapat melakukan aktivitas belajar di rumah menggunakan handphone maupun laptop, dan diharapkan dengan kemudahan pembelajaran daring saat ini dapat membuat hasil belajar siswa lebih baik. Hasil belajar yang diteliti dalam penelitian ini adalah hasil belajar pada mata pelajaran Administrasi Umum di kelas X OTKP. Mata pelajaran ini terdapat banyak teori daripada praktik sehingga diperlukan penguasaan materi agar lebih mudah dipahami oleh siswa kelas X OTKP.

SMK Muhammadiyah 7 Gondanglegi Malang merupakan sekolah rujukan nasional sejak 2014 serta sekolah ini sudah terakreditasi A. Sekolah ini memiliki fasilitas yang dapat dikatakan lengkap untuk penunjang pembelajaran dan sudah memiliki 13 jurusan, antara lain: Teknik Kendaraan Ringan, Teknik Instalasi Tenaga Listrik, Teknik Sepeda Motor, Teknik Ototronik, Teknik Alat Berat, Teknik Komputer \& Jaringan, Perbankan, Otomatisasi Tata Kelola Perkantoran, Perhotelan, Farmasi, Keperawatan, Tata Boga, dan Multimedia. Menurut (Fatimatuzzahroh and Puspasari, 2021), Vocational High Schools (SMK) is encouraged to direct students in developing and shaping abilities in their fields of expertise. With the hope that students can immediately jump into the world of work with the knowledge and practices that have been learned in school. Dengan kata lain Sekolah Menengah Kejuruan (SMK) dituntut untuk mengarahkan siswa dalam mengembangkan serta membentuk kemampuan dibidang keahliannya. Dengan harapan siswa dapat langsung terjun pada dunia kerja dengan bekal pengetahuan dan praktik yang telah dipelajari di sekolah.

Diketahui dari permasalahan yang ada maka tujuan dalam penelitian ini adalah untuk menganalisis pengaruh penggunaan pembelajaran daring terhadap hasil belajar siswa pada mata pelajaran Administrasi Umum kelas X OTKP SMK Muhammadiyah 7 Gondanglegi Malang. 
Berdasarkan kajian pustaka yang telah dipaparkan tersebut, hipotesis dalam penelitian ini adalah: $\mathrm{H}_{\mathrm{a}}$ : terdapat pengaruh signifikan penggunaan pembelajaran daring terhadap hasil belajar siswa pada mata pelajaran Administrasi Umum kelas X OTKP SMK Muhammadiyah 7 Gondanglegi Malang $\mathrm{H}_{0}$ : tidak terdapat pengaruh signifikan penggunaan pembelajaran daring terhadap hasil belajar siswa pada mata pelajaran Administrasi Umum kelas X OTKP SMK Muhammadiyah 7 Gondanglegi Malang.

\section{METODE}

Penelitian ini merupakan penelitian deskriptif dengan pendekatan kuantitatif. Penelitian deskriptif menurut (Sugiyono, 2018) adalah penelitian yang berkenaan dengan nilai variabel mandiri, baik pada satu variabel atau lebih serta dalam penelitiannya tidak membuat perbandingan pada sampel lain atau menghubungkan dengan variabel yang lainnya.

Menurut (Sugiyono, 2018), penelitian kuantitatif adalah penelitian yang berlandaskan pada filsafat positivisme, digunakan untuk meneliti pada populasi atau sampel tertentu, pengumpulan data menggunakan instrumen penelitian, dan analisis data. Populasi dalam penelitian ini adalah seluruh siswa kelas X OTKP sebanyak 113 siswa yang terdiri dari X OTKP 1 sebanyak 40 siswa, X OTKP 2 sebanyak 39 siswa, dan X OTKP 3 sebanyak 34 siswa. Menurut (Sugiyono, 2018), populasi adalah wilayah generalisasi yang terdiri atas objek atau subjek yang mempunyai kualitas dan karakteristik tertentu yang diterapkan oleh penelitian untuk dipelajari dan ditarik kesimpulan. Sedangkan yang dimaksud dengan sampel menurut (Sugiyono, 2018) adalah bagian dari jumlah dan karakteristik yang dimiliki populasi tersebut. Sampel dalam penelitian ini ditentukan dengan menggunakan rumus Yamane menurut (Sugiyono, 2018), yaitu sebanyak 88 siswa dengan menggunakan rumus sebagai berikut:

$$
n=\frac{\mathrm{N}}{1+N(e)^{2}}
$$

\section{Keterangan:}

$$
\begin{array}{ll}
\mathrm{n} & =\text { jumlah sampel } \\
\mathrm{N} & =\text { jumlah populasi } \\
\mathrm{e} & =\text { batas toleransi kesalahan }(5 \%)
\end{array}
$$

Teknik pengambilan sampel dalam penelitian ini menggunakan proportional random sampling. Proportional random sampling adalah teknik yang lebih leluasa dalam penggunaannya, maksudnya dapat digunakan pada populasi berstrata, populasi area ataupun populasi cluster, hal terpenting dalam teknik ini yakni penggunaan perwakilan berimbang, karena itu peneliti harus mengenal lebih dulu ciri-ciri tertentu dari populasi yang ada (Bungin, 2009). Teknik proportional random sampling dalam penelitian ini dapat dijabarkan pada tabel 1 berikut ini:

\section{Tabel 1. Perhitungan Sampel Penelitian}

\begin{tabular}{llll}
\hline No. & \multicolumn{1}{c}{ Kelas } & Populasi & Sampel \\
\hline 1. & X OTKP 1 & 40 & 31 \\
2. & X OTKP 2 & 39 & 30 \\
3. & X OTKP 3 & 34 & 27 \\
& Jumlah & 113 & 88 \\
\hline
\end{tabular}

Sumber: Data Diolah Peneliti (2021)

Penelitian ini terdiri dari variabel independen $(X)$ yaitu penggunaan pembelajaran daring dan variabel dependen (Y) yaitu hasil belajar siswa. Model konseptual penelitian ini dapat dilihat pada Gambar 1. 


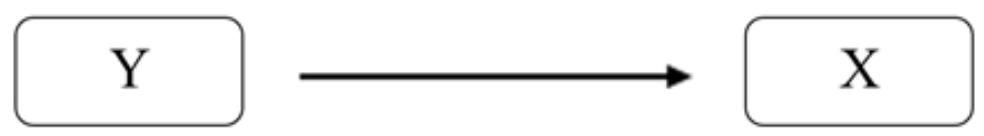

Gambar 1. Model Konseptual Penelitian

Sumber: Data Diolah Peneliti (2021)

Keterangan:

$\mathrm{X} \quad=$ Penggunaan Pembelajaran Daring

$\mathrm{Y} \quad=$ Hasil Belajar Siswa

$\rightarrow \quad=$ Pengaruh antar variabel

Penelitian ini menggunakan uji coba instrumen yang terdiri dari: 1) uji validitas digunakan untuk mengetahui sejauh mana ketepatan dan kecermatan alat ukur melakukan fungsi ukurnya. Uji validitas dilakukan dengan membandingkan nilai $r$ hitung dengan $r$ tabel, data yang diolah dapat dikatakan valid jika nilai $r$ hitung $>r$ tabel, sedangkan apabila $r$ hitung $<\mathrm{r}$ tabel maka data tersebut tidak valid (Nurhasanah, 2016); 2) uji reliabilitas digunakan untuk mengetahui alat ukur yang digunakan dalam mengukur konsep yang hendak diukur dan menunjukkan sejauh mana suatu hasil pengukuran relatif konsisten apabila pengukuran dilakukan berulang kali. Uji reliabilitas menggunakan Cronbach Alpha sebesar 0,60. Data dapat dikatakan reliabel apabila nilai alpha $<0,60$ maka dapat dikatakan tidak reliabel sedangkan jika nilai alpha $>0,60$ maka dapat dikatakan reliabel (Nurhasanah, 2016). Uji validitas dan uji reliabilitas dilakukan dengan menggunakan program aplikasi SPSS 18.

Penelitian ini menggunakan teknik analisis data sebagai berikut: 1) uji asumsi klasik mencakup a) uji normalitas, untuk menguji data variabel bebas (X) dan data variabel terikat (Y) pada persamaan regresi yang dihasilkan, apakah berdistribusi normal atau berdistribusi tidak normal (Sunyoto, 2013) Uji normalitas dilakukan dengan metode uji One-Sample Kolmogorov-Smirnov dengan hasil output dapat dilihat jika nilai signifikansi $>0,05$ maka data berdistribusi normal; b) uji heteroskedastisitas adalah keadaan dimana terjadinya ketidaksamaan varian dari residual. Uji heteroskedastisitas menggunakan sprearman's rho untuk menganalisis data yang diperoleh dengan melihat titik-titik pada grafik scartterplots, data terjadi heteroskedastisitas jika terdapat titik-titik yang membentuk suatu pola tertentu yang teratur (gelombang, melebar kemudian menyempit) sedangkan jika data tidak terjadi heteroskedastisitas apabila hasil output menujukkan tidak ada pola yang jelas seperti titik-titik menyebar di atas dan di bawah angka 0 pada sumbu $Y$, diketahui regresi yang baik seharusnya tidak terjadi heteroskedastisitas (Priyatno, 2012); 2) uji hipotesis menggunakan regresi linier sederhana yang digunakan untuk menganalisis apakah terdapat pengaruh penggunaan pembelajaran daring (X) terhadap hasil belajar siswa (Y). Baik uji asumsi klasik maupun uji hipotesis menggunakan program aplikasi SPSS 18.

\section{HASIL}

Uji validitas berdasarkan pengolahan data melalui program aplikasi SPSS 18 dapat dinyatakan bahwa 34 item pernyataan dinyatakan valid karena nilai $r$ hitung lebih besar daripada $r$ tabel. Sedangkan untuk hasil uji reliabilitas menyatakan hasil tabel reliability statistics menunjukkan nilai Cronbach's Alpha variabel penggunaan pembelajaran daring $(X)$ sebesar $0,937>0,60$ sehingga dapat disimpulkan bahwa instrumen penelitian ini dikatakan reliabel. 


\section{Uji Normalitas}

One-Sample Kolmogorou-Smirnơv Test

\begin{tabular}{|c|c|c|}
\hline & & $\begin{array}{l}\text { Unstandarda } \\
\text { ed Residual }\end{array}$ \\
\hline $\mathrm{N}$ & & 88 \\
\hline \multirow[t]{2}{*}{ Nomal Parameters ${ }^{\text {bt }}$} & Mean & 0000000 \\
\hline & Sud Dedation & 4.69305492 \\
\hline \multirow[t]{3}{*}{ Mast Eutreme Differences } & Absoluse & .089 \\
\hline & Posithe & 093 \\
\hline & Negative & -099 \\
\hline Kolmogorm-Gmimor $Z$ & & .933 \\
\hline Astmo. Big (2-tailed) & & .349 \\
\hline
\end{tabular}

a. Tast distribution is Nomal.

\section{Tabel 2. Hasil Uji Normalitas}

Sumber: Data Diolah Peneliti (2021)

Uji normalitas menggunakan metode uji One-Sample Kolmogorov-Smirnov, diketahui output pada tabel 2 jika nilai Sig. $>0,05$ maka data tersebut berdistribusi dengan normal, sedangkan jika nilai Sig. $<0,05$ data tersebut tidak berdistribusi dengan normal. Berdasarkan hasil uji normalitas, diperoleh nilai Sig. sebesar 0,349. Sehingga 0,349>0,05, dengan ini data tersebut dapat dinyatakan telah berdistribusi normal.

\section{Uji Heteroskedastisitas}

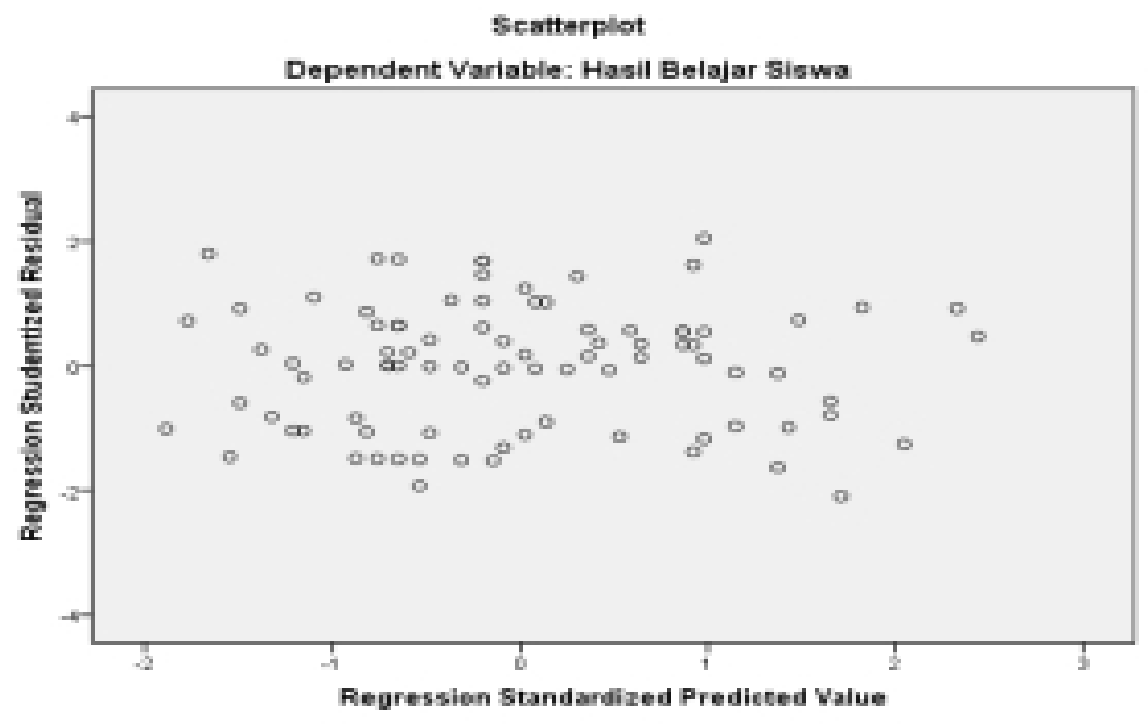

Gambar 2. Hasil Uji Heteroskedastisitas

Sumber: Data Diolah Peneliti (2021)

Berdasarkan uji heteroskedastisitas dengan melihat gambar scatterplot, diketahui bahwa titik-titik data menyebar di atas dan di bawah atau sekitar 0 pada sumbu Y dan penyebaran titik-titik data tidak membentuk suatu pola, sehingga dapat disimpulkan bahwa data tidak terjadi heteroskedastisitas. 


\section{Pengujian Hipotesis}

Tabel 3. Hasil Uji Regresi Linier Sederhana

\begin{tabular}{|c|c|c|c|c|c|c|}
\hline \multirow[t]{2}{*}{ Wode } & & \multicolumn{2}{|c|}{ Uestandardagd Coefieliarts } & \multirow{2}{*}{$\begin{array}{c}\text { Standandiegd } \\
\text { Coaficients } \\
\text { Bata }\end{array}$} & \multirow[b]{2}{*}{1} & \multirow[b]{2}{*}{ Sig. } \\
\hline & & $B$ & Sid. Emor & & & \\
\hline \multirow[t]{2}{*}{1} & (Constant) & 83.222 & 3.548 & & 23.454 & .000 \\
\hline & $\begin{array}{l}\text { Penzygunaan } \\
\text { Pemialagaran Daring }\end{array}$ & 016 & 028 & .060 & .558 & .578 \\
\hline
\end{tabular}

a. Desendent Variala: Hasil Belajar Siswa

Sumber: Data Diolah Peneliti (2021)

Berdasarkan tabel 3 tersebut dapat diketahui model persamaan regresi linier sederhana sebagai berikut: $\mathrm{Y}=83,222+0,016 \mathrm{X}$ Dimana $\mathrm{Y}$ adalah hasil belajar siswa dan $\mathrm{X}$ adalah penggunaan pembelajaran daring. Persamaan regresi linier sederhana tersebut mempunyai makna sebagai berikut: (1)Konstanta $=83,222$, Artinya apabila variabel independen yaitu penggunaan pembelajaran daring (X) bernilai 0, maka variabel dependen yaitu hasil belajar siswa $(Y)=83,222$. (2) Koefisien $\mathrm{X}$ (penggunaan pembelajaran daring) $=0,016$ Artinya setiap variabel penggunaan pembelajaran daring mengalami kenaikan sebesar satu satuan, maka akan menyebabkan peningkatan terhadap hasil belajar siswa sebesar 0,016 satuan. Hasil uji regresi linier sederhana dapat dilihat pada penggunaan pembelajaran daring $(\mathrm{X})$ tidak berpengaruh signifikan terhadap hasil belajar siswa dengan memperoleh nilai sig. $0,578>0,05$ dan $t_{\text {hitung }} 0,558<t_{\text {tabel }} 1,987$ yang artinya Ha ditolak.

\section{PEMBAHASAN}

Berdasarkan hasil uji-t dapat diketahui bahwa nilai sig. sebesar 0,578 $>0,05$ dan $t_{\text {hitung }}$ $0,558<\mathrm{t}_{\text {tabel }} 1,987$ yang menunjukkan bahwa $\mathrm{H}_{\mathrm{a}}$ ditolak, hal ini dapat disimpulkan bahwa tidak terdapat pengaruh signifikan penggunaan pembelajaran daring terhadap hasil belajar siswa pada mata pelajaran Administrasi Umum kelas X OTKP SMK Muhammadiyah 7 Gondanglegi Malang. Penelitian ini sejalan dengan penelitian yang dilakukan oleh (Nisa, 2012) yang menyatakan bahwa tidak ada pengaruh pembelajaran e-learning terhadap hasil belajar mata kuliah Statistics mahasiswa Tadris Bahasa Inggris Semester II Tahun 2010/2011, hal ini disebabkan oleh keterbatasan akses internet mahasiswa karena tidak dapat dipungkiri bahwa modal utama pembelajaran e-learning adalah kemudahan akses internet, serta kurangnya konsistensi dosen dalam pendampingan di kelas online. Penelitian (Astini, 2020) juga menjelaskan bahwa perkuliahan online tidak efektif, hal ini disebabkan karena belum terbiasa melakukan perkuliahan secara online dengan persentase sebesar $61,5 \% ; 50 \%$ mahasiswa menyatakan belum mempunyai fasilitas laptop; $50 \%$ mahasiswa dalam perkuliahan online menggunakan handphone sebagai media perkuliahan online, dan $80 \%$ mahasiswa menyatakan susah mendapatkan sinyal dan boros penggunaan paket data, yang disebabkan banyak mahasiswa yang tinggal jauh dari daerah perkotaan. Penelitian (Widodo et al., 2020) menjelaskan bahwa terdapat $81,60 \%$ siswa mengaku kesulitan mengikuti pembelajaran online; $18,40 \%$ siswa yang dapat mengikuti pembelajaran online dengan baik; serta sebanyak $86,60 \%$ siswa belum bisa memahami materi pelajaran dengan baik melalui media online, dimana belum adanya pelatihan online, siswa juga memiliki keterbatasan biaya, dan jika melakukan pembelajaran melalui online masih banyak siswa kesulitan koneksi internet. Penelitian (Zboun and Farrah, 2021) mengemukakan bahwa berdasarkan survei yang diberikan kepada 82 siswa menunjukkan hasil bahwa siswa tidak puas dengan pembelajaran pada kelas online dikarenakan mereka lebih menyukai pembelajaran konvensional, pembelajaran online menyebabkan siswa kurang berinteraksi dengan guru serta dalam pembelajaran online siswa kurang termotivasi mengikuti pembelajaran.

Dalam pembelajaran daring semangat belajar sangat diperlukan, namun setiap siswa pastinya berbeda-beda ketika melakukan pembelajaran daring tentu ada yang semangat, kurang semangat, dan tidak semangat dalam mengikuti pembelajaran. Akan tetapi pada kenyataannya banyak siswa yang 
kurang bersemangat dalam proses pembelajaran daring berlangsung, koneksi dan jaringan internet yang kurang stabil pada saat melakukan pembelajaran daring meskipun banyak dari siswa yang sudah menggunakan wifi sehingga hal ini menyebabkan siswa kesulitan untuk mengikuti pembelajaran daring. Terlebih lagi jika cuaca hujan berlangsung saat pembelajaran daring membuat kegiatan pembelajaran berjalan kurang lancar karena dapat membuat koneksi sinyal lemah sehingga sulit untuk mengakses internet. Disamping masih sedikit siswa kelas X OTKP yang mempunyai laptop sebagai penunjang kegiatan belajar pada saat ini sehingga siswa melakukan pembelajaran daring menggunakan handphone, sedangkan dengan penggunaan handphone saat pembelajaran sangat kurang membantu siswa terlebih lagi jika siswa harus mengerjakan tugas atau soal yang diketik melalui microsoft word. Siswa yang menggunakan handphone mengalami kesulitan untuk mengerjakan tugas dan akan lebih lama untuk mengumpulkan tugas. Selama pembelajaran daring berlangsung, guru masih kurang memantau siswa yang membuat kurangnya interaksi antara guru dan siswa sehingga siswa kurang aktif dalam mengikuti pembelajaran daring.

Namun penelitian ini bertolak belakang dengan penelitian yang dilakukan oleh (Wasito, 2021) yang menyatakan bahwa pembelajaran online memiliki pengaruh signifikan terhadap hasil belajar Taruna Diploma III Teknik Bangunan dan Landasan Angkatan 4A dan 4B Semester II di Politeknik Penerbangan Surabaya. Penelitian (Liu and Ilyas, 2020) menjelaskan bahwa pembelajaran online berbasis zoom cloud meeting berpengaruh terhadap hasil belajar, sehingga pembelajaran online berbasis zoom cloud meeting dapat menjadi salah satu alternatif media pembelaja(Utomo, 2020)ran online selama belajar dari rumah. Penelitian (Yuliana and Listiadi, 2021) mengungkapkan bahwa e-learning mempengaruhi hasil belajar komputer akuntansi. Hasil penelitian (Utomo, 2020) mengemukakan bahwa terdapat pengaruh signifikan Study From Home (SFH) terhadap hasil belajar siswa kelas 12 IPS III SMAN 2 Kota Semarang. (Ismail, 2017) dalam penelitiannya menunjukkan bahwa terdapat pengaruh penggunaan internet terhadap hasil belajar IPS peserta didik kelas X SMK Nurul Huda Sukaraja OKU Timur, serta menyatakan bahwa sumber belajar dapat mempengaruhi hasil belajar peserta didik. Semakin banyak referensi yang digunakan sebagai acuan terlebih dengan adanya internet sangat memberi dampak positif dan mampu memberikan kontribusi yang cukup besar terhadap hasil belajar yang akan diraih peserta didik. Hasil penelitian (Fitriyani, Fauzi and Sari, 2020) menjelaskan bahwa mahasiswa program studi Pendidikan Guru Sekolah Dasar Universitas Kuningan memiliki motivasi yang sangat tinggi terhadap pembelajaran daring selama masa pandemi covid-19, pada masa pandemi covid-19 tidak menghalangi motivasi mahasiswa dalam melakukan kegiatan pembelajaran secara daring. (Pratama and Meilani, 2020) hasil belajar merupakan tolak ukur keberhasilan siswa dalam proses pembelajaran baik berupa nilai maupun perubahan dari segi sikap belajarnya, dan merupakan sebuah dasar untuk mengetahui sejauh mana siswa telah mencapai standar kompetensi yang telah ditetapkan. Sedangkan (Saputra, Ismet, and Andrizal, 2018) menyatakan bahwa hasil belajar menjadi salah satu acuan terhadap keberhasilan dalam proses pendidikan, hasil belajar dapat berupa kemampuan-kemampuan yang dimiliki siswa, kemampuan inilah yang didapat setelah melalui dan menerima pengalaman-pengalaman dalam proses belajar yang dilakukan siswa. (Liubana and Puspasari, 2021) juga menjelaskan bahwa penggunaan e-learning dengan google classroom dapat diterima dengan baik oleh mahasiswa dan dapat memberikan pengaruh terhadap motivasi belajar mahasiswa brothers and sisters house kota Surabaya pada masa pandemi Covid-19.

Penelitian (Halik and Aini, 2020) mengatakan bahwa selama proses pembelajaran daring di masa pandemi covid-19, siswa relatif aktif mengikuti kegiatan belajar. Hasil rata-rata keaktifan siswa berada pada kategori tinggi pada aktivitas visual seperti membaca buku terkait topik yang akan dipelajari, membaca materi sebelum mengerjakan tugas, memperhatikan ketika guru menjelaskan materi, aktivitas mendengarkan seperti menyimak penjelasan guru, mendengarkan perintah tugas yang diberikan guru, serta aktivitas menulis seperti mengerjakan tugas, menyusun laporan atau catatan dengan rapi serta teliti dalam mengerjakan tugas. Penelitian (Verawati, 2020) juga mengungkapkan bahwa penggunaan e-learning efektif dalam meningkatkan kemampuan berpikir kritis mahasiswa. Dalam konteks akses penggunaan e-learning, institusi mendukung dan memfasilitasi secara penuh pelaksanaan pengajaran menggunakan e-learning. 


\section{SIMPULAN}

Berdasarkan hasil dan pembahasan, maka dapat disimpulkan bahwa tidak terdapat pengaruh signifikan penggunaan pembelajaran daring terhadap hasil belajar siswa pada mata pelajaran Administrasi Umum kelas X OTKP SMK Muhammadiyah 7 Gondanglegi Malang dengan nilai sig. sebesar 0,578 $>0,05$ dan $\mathrm{t}_{\text {hitung }} 0,558<\mathrm{t}_{\text {tabel }} 1,987$ yang artinya $\mathrm{H}_{\mathrm{a}}$ ditolak.

\section{SARAN}

Adapun saran yang dapat diberikan oleh peneliti, yaitu: 1) diharapkan guru dapat meningkatkan pembelajaran yang inovatif dan kreatif yang bervariasi dengan memanfaatkan media pembelajaran daring agar tidak monoton dan membuat siswa lebih semangat dalam mengikuti pembelajaran daring; 2) diharapkan siswa dapat diberikan fasilitas yang menunjang pembelajaran daring di sekolah secara bergantian atau dengan membagi shift kepada siswa untuk menggunakan komputer dan akses internet yang sudah disediakan sekolah apabila tidak memiliki laptop di rumah agar dapat menunjang pembelajaran daring.

\section{DAFTAR RUJUKAN}

Abdeldayem, M. M., Aldulaimi, S. H. and Abdulrazaq, M. L. (2020). Virtual Learning and Students' Connectedness in the Time of Coronavirus. International Journal of Advanced Science and Technology, 29(5), p. 12. http:// sersc.org/journals/index.php/IJAST/article/view/25862.

Amiruddin. (2016). Perencanaan Pembelajaran (Konsep dan Implementasi). Bantul Yogyakarta: Parama Ilmu.

Astini, N. K. S. (2020). Tantangan Dan Peluang Pemanfaatan Teknologi Informasi Dalam Pembelajaran Online Masa Covid-19. Jurnal Ilmu Pendidikan, 3(2), pp. 241-255. http://jayapanguspress.penerbit.org/index.php/ cetta/article/view/452.

Bahasoan, A. et al. (2020). Effectiveness of Online Learning In Pandemic Covid-19. International Journal of Science, Technology \& Management, 1(2), pp. 100-106. https://ijstm.inarah.co.id/index.php/ijstm/article/ view/30.

Bungin, B. (2009) Metodologi Penelitian Kuantitatif (Komunikasi, Ekonomi, Kebijakan Publik Serta Ilmu-ilmu Sosial Lainnya). Pertama. Jakarta: Kencana.

Fatimatuzzahroh, S. and Puspasari, D. (2021). The Influence Of Using Typing Master Application Media on 10 Finger Typing Skills in Office Technology Subjects at SMK Muhammadiyah 2 Sumberrejo Bojonegoro. 5(36), pp. 1-6. https://iocscience.org/ejournal/index.php/mantik/article/view/1249.

Fitriyani, Y., Fauzi, I. and Sari, M. Z. (2020). Motivasi Belajar Mahasiswa Pada Pembelajaran Daring Selama Pandemik Covid-19. Jurnal Kependidikan: Jurnal Hasil Penelitian dan Kajian Kepustakaan di Bidang Pendidikan, Pengajaran dan Pembelajaran, 6(2), pp. 165-175. https://e-journal.undikma.ac.id/index.php/ jurnalkependidikan/article/view/2654.

Halik, A. and Aini, Z. (2020). Analisis Keaktifan Siswa dalam Proses Pembelajaran Daring di Masa Pandemi COVID-19. Enlighten (Jurnal Bimbingan dan Konseling Islam), 3(2), pp. 131-141. https://www.journal. iainlangsa.ac.id/index.php/enlighten/article/view/1887.

Ida, F. M. and Maksum, H. (2020). Contribution of Learning Style, Learning Creativity and Exploratory Interest to Students' Simulation and Digital Communication Learning Outcomes during the Covid-19 Pandemic. Journal of Education Technology., 4(4), pp. 404-414. https://www.journal.iainlangsa.ac.id/index.php/ enlighten/article/view/1887.

Ismail, K. (2017). Pengaruh Penggunaan Internet terhadap Hasil Belajar IPS Peserta Didik Kelas X SMK Nurul Huda Sukaraja Oku Timur. Utility : Jurnal Ilmiah Pendidikan dan Ekonomi, 1(1), pp. 58-64. http://journal. stkipnurulhuda.ac.id/index.php/utility/article/view/63.

Ismawati, L. (2017). Pengaruh Media Pembelajaran dan Motivasi Berprestasi Terhadap Hasil Belajar Peserta Didik MAN Di Kabupaten Gresik. Jurnal Pendidikan Ekonomi, 01(2), pp. 091-104. https://journal.unesa. ac.id/index.php/jpeka/article/view/1948.

Liu, A. N. A. M. and Ilyas, I. (2020). Pengaruh Pembelajaran Online Berbasis Zoom Cloud Meeting Terhadap Hasil Belajar Mahasiswa Fisika Universitas Flores', Jurnal Pendidikan Fisika dan Keilmuan (JPFK), 6(1), p. 34. http://e-journal.unipma.ac.id/index.php/JPFK/article/view/7303. 
Liubana, A. and Puspasari, D. (2021). Analisis Pengaruh Penggunaan E-Learning dengan Google Classroom dan Disiplin Belajar terhadap Motivasi Belajar Mahasiswa Brothers and Sisters House Kota Surabaya pada Masa Pandemi Covid-19. Jurnal Kependidikan: Jurnal Hasil Penelitian dan Kajian Kepustakaan di Bidang Pendidikan, Pengajaran dan Pembelajaran, 7(2), pp. 417-427. https://e-journal.undikma.ac.id/index.php/ jurnalkependidikan/article/view/3599.

Melinda, N. and Lazwardi, A. (2020). Kemampuan Disposisi Matematis Siswa pada Pembelajaran Daring di Masa Pandemi Covid-19. Prosiding Konferensi Nasional Pendidika, pp. 59-65. FKIP Universitas Muhammadiyah Banjarmasin. https://urbangreen.co.id/proceeding/index.php/library/article/view/12.

Munir (2009) Pembelajaran Jarak Jauh Berbasis Teknologi Informasi Komunikasi. Bandung: CV Alfabeta.

Mustakim, U. S. (2020). Efektivitas Pembelajaran di Era New Normal terhadap Hasil Belajar Mahasiswa pada Mata Kuliah Matematika Diskrit. Uniqbu Journal of Exact Sciences, 1(1), pp. 41-45. http://ejournal-uniqbu. ac.id/index.php/ujes/article/view/15.

Nisa, L. C. (2012). Pengaruh Pembelajaran E-Learning Terhadap Hasil Belajar Mata Kulliah Statistics Mahasiswa Tadris Bahasa Inggris Fakultas Tarbiyah IAIN Walisongo. Phenomenon : Jurnal Pendidikan MIPA, 2(1), pp. 7-27. https://journal.walisongo.ac.id/index.php/Phenomenon/article/view/416.

Nurhasanah, S. (2016) Praktikum Statistika 2 untuk Ekonomi dan Bisnis Aplikasi dengan Ms Excel dan SPSS. Jakarta: Salemba Empat.

Prasetya, T. A. and Harjanto, C. T. (2020). PENGARUH MUTU PEMBELAJARAN ONLINE DAN TINGKAT KEPUASAN MAHASISWA TERHADAP HASIL BELAJAR SAAT PANDEMI COVID19. Jurnal Pendidikan Teknologi dan Kejuruan, 17(2), pp. 188-197. https://ejournal.undiksha.ac.id/index.php/JPTK/ article/view/25286.

Pratama, E. and Meilani, R. I. (2020). Motivasi dan Hasil Belajar : Sebuah Studi pada Siswa Mata Pelajaran Kearsipan Di SMK. Jurnal Pendidikan Manajemen Perkantoran, 5(1), pp. 56-66. https://ejournal.upi.edu/ index.php/jpmanper/article/view/25851.

Priyatno, D. (2012) Belajar Cepat Olah Data Statistik dengan SPSS. Yogyakarta: ANDI.

Saputra, H. D., Ismet, F., and Andrizal (2018). Pengaruh Motivasi Terhadap Hasil Belajar Siswa SMK. INVOTEK: Jurnal Inovasi Vokasional dan Teknologi, 18(1), pp. 25-30. http://invotek.ppj.unp.ac.id/index.php/invotek/ article/view/168.

Shereen, M. A. et al. (2020). COVID-19 infection: Emergence, transmission, and characteristics of human coronaviruses. Journal of Advanced Research, 24, pp. 91-98. https://www.sciencedirect.com/science/article/ pii/S2090123220300540.

Sugiyono (2018). Metode Penelitian Kuantitatif. Bandung: Alfabeta.

Sunyoto, D. (2013). Analisis Regresi dan Uji Hipotesis. Jakarta: PT Buku Kita.

Utomo, V. B. S. (2020) 'Pengaruh "Study From Home” (SFH) dalam Pembelajaran Online Bagi Peserta Didik Kelas 12 IPS III SMAN 2 Kota Semarang dalam Menghadapi Pandemik COVID-19 di Kota Semarang', Jurnal Ilmu Pengetahuan Sosial, 7(3), pp. 513-521. http://jurnal.um-tapsel.ac.id/index.php/nusantara/article/ view/1818.

Valentina, H. S., Nugrahadi, E. W. and Budiarta, K. (2019). The Effect of Learning Strategy and Thinking Ability on The Students' Learning Outcomes in Economics Subject of XI Social Students in Senior High School State 1 in Pematang Siantar. Budapest International Research and Critics in Linguistics and Education (BirLE) Journal, 2(4), pp. 451-460. https://bircu-journal.com/index.php/birle/article/view/543.

Verawati, N. N. S. P. (2020). Efektivitas Penggunaan E-Learning dalam Pengajaran di Kelas untuk Meningkatkan Kemampuan Berpikir Kritis Mahasiswa. Jurnal Ilmiah IKIP Mataram, 7(2), pp. 168-175. https://e-journal. undikma.ac.id/index.php/jiim/article/view/3375.

Wasito, B. (2021). Pengaruh Pembelajaran Online Terhadap Hasil Belajar Taruna Diploma III Teknik Bangunan dan Landasan Angkatan 4A dan 4B Semester II di Politeknik Penerbangan Surabaya. Junal Penelitian Politeknik Penerbangan, 6(1), pp. 64-77. https://ejournal.poltekbangsby.ac.id/index.php/jurnalpenelitian/ article/view/550.

Widiyono, A. (2020). Efektifitas Perkuliahan Daring (Online) pada Mahasiswa PGSD di Saat Pandemi Covid 19. Jurnal Pendidikan, 8(2), pp. 169-177. https://unimuda.e-journal.id/jurnalpendidikan/article/view/458.

Widodo, A. et al. (2020). From face-to-face learning to web base learning: How are student readiness?. Premiere Educandum : Jurnal Pendidikan Dasar dan Pembelajaran, 10(2), pp. 149-169. http://e-journal.unipma.ac.id/ index.php/PE/article/view/6801. 
Wilson, A. (2020). Penerapan Metode Pembelajaran Daring (Online) melalui Aplikasi Berbasis Android saat Pandemi Global. SAP (Susunan Artikel Pendidikan), 5(1), pp. 66-72. https://journal.lppmunindra.ac.id/index. $\mathrm{php} / \mathrm{SAP} / \mathrm{article} / \mathrm{view} / 6386$.

Yuliana, Y. and Listiadi, A. (2021). Pengaruh Pemahaman Siklus Akuntansi, Computer Attitude, Intensitas Latihan Soal dan E-Learning terhadap Hasil Belajar Komputer Akuntansi. Jurnal Pendidikan Akuntansi (JPAK), 9(1), pp. 104-115. https://ejournal.unesa.ac.id/index.php/jpak/article/view/39273.

Zboun, J. S. and Farrah, M. (2021). Students' Perspetives of Online Language Learning During Corona Pandemic: Benefits and Challenges. Indonesian EFL Journal (IEFLJ), 7(1), pp. 13-20. https://journal.uniku.ac.id/index. php/IEFLJ/article/view/3986. 